\title{
Does galvanic cathodic protection by aluminum anodes impact marine organisms?
}

\author{
Anna Maria Bell', Marcus von der Au ${ }^{2,4}$, Julia Regnery', Matthias Schmid 3 , Björn Meermann², \\ Georg Reifferscheid ${ }^{1}$, Thomas Ternes ${ }^{2}$ and Sebastian Buchinger ${ }^{1 *}$ (D)
}

\begin{abstract}
Background: Cathodic protection by sacrificial anodes composed of aluminum-zinc-indium alloys is often applied to protect offshore support structures of wind turbines from corrosion. Given the considerable growth of renewable energies and thus offshore wind farms in Germany over the last decade, increasing levels of aluminum, indium and zinc are released to the marine environment. Although these metals are ecotoxicologically well-studied, data regarding their impact on marine organisms, especially sediment-dwelling species, as well as possible ecotoxicological effects of galvanic anodes are scarce. To investigate possible ecotoxicological effects to the marine environment, the diatom Phaedacty/um tricornutum, the bacterium Alivibrio fischeri and the amphipod Corophium volutator were exposed to dissolved galvanic anodes and solutions of aluminum and zinc, respectively, in standardized laboratory tests using natural seawater. In addition to acute toxicological effects, the uptake of these elements by C. volutator was investigated.
\end{abstract}

Results: The investigated anode material caused no acute toxicity to the tested bacteria and only weak but significant effects on algal growth. In case of the amphipods, the single elements Al and Zn showed significant effects only at the highest tested concentrations. Moreover, an accumulation of Al and In was observed in the crustacea species.

Conclusions: Overall, the findings of this study indicated no direct environmental impact on the tested marine organisms by the use of galvanic anodes for cathodic protection. However, the accumulation of metals in, e.g., crustaceans might enhance their trophic transfer within the marine food web.

Keywords: Galvanic anodes, Metal toxicity, Metal uptake, Corophium volutator, Seawater

\section{Background}

Offshore installations, such as wind turbines, are founded on support structures that mainly consist of steel. In order to ensure sufficient durability of submerged substructures, appropriate corrosion protection strategies are required. Because of its comparatively low weight and high electrochemical capacity, aluminum-zinc-indium alloys are commonly applied as sacrificial (i.e., galvanic) anodes for cathodic corrosion protection of steel in the marine environment [1]. The galvanic anode and the

\footnotetext{
*Correspondence: buchinger@bafg.de

1 Department G3 - Biochemistry, Federal Institute of Hydrology,

Ecotoxicology, Am Mainzer Tor 1, Koblenz 56068, Germany

Full list of author information is available at the end of the article
}

steel are combined to an electrochemical local element resulting in a continuous oxidation of the galvanic anode and thus transfer of electrons to the steel that exhibits a higher standard electrode potential [2,3]. As numbers of offshore wind farms increase to meet the goals of the European strategy for a "prosperous, modern, competitive and climate neutral economy" [4], an increasing amount of galvanic anodes is expected to be used in the marine environment. More than 5,000 offshore wind turbines have been installed across 12 European countries until 2019, which corresponds to a total capacity of around $22 \mathrm{GW}$. The majority (77\%) of this capacity is located in the North Sea [5]. The necessary amount of a certain anode material mainly depends on its desired life time and the surface area (i.e. foundation type) that 
requires protection against corrosion [6]. A conservative estimate based on calculations from Kirchgeorg et al. [7] reveals a current annual release of around $1900 \mathrm{t}$ aluminum and $90 \mathrm{t}$ zinc solely to the North Sea. This evaluation assumes the exclusive installation of aluminum anodes (Al-Zn-In alloy) with a life time of 25 years on uncoated monopile foundations without considering offshore substations or converter platforms. By the end of 2030 the wind capacity in Europe is expected to grow to $76 \mathrm{GW}$ [5], which more than triples the need of corrosion protection as well.

The release of metals into the marine environment due to the use of galvanic anodes raises questions regarding potential environmental effects on marine organisms either directly or along the food chain across trophic levels [8]. In laboratory experiments, Deborde et al. demonstrated a significant increase of suspended and dissolved metal fractions in the water phase. The total concentrations reached up to $7280 \mu \mathrm{g} / \mathrm{l} \mathrm{Al}$ and $360 \mu \mathrm{g} / \mathrm{l} \mathrm{Zn}$ during the activation period of the galvanic anode [9]. A field study in a French harbor reported elevated Al concentrations up to $32.5 \mathrm{~g} / \mathrm{kg}$ in sediments sampled close to galvanic anodes. Furthermore, up to $380 \mathrm{mg} / \mathrm{kg}$ acidsoluble $\mathrm{Al}$ was detected [10]. This increased proportion of a labile $\mathrm{Al}$ fraction might indicate a higher bioavailability of $\mathrm{Al}$ released by galvanic anodes. Leleyter et al. observed a total Al concentration of $29 \mathrm{~g} / \mathrm{kg}$ in natural sediments contaminated by aluminum anodes [11]. Moreover, galvanic anodes caused local elevations of $\mathrm{Zn}$ concentrations, both in sediment and dissolved in seawater. Up to $23 \mu \mathrm{g} / \mathrm{l}$ dissolved and $300 \mu \mathrm{g} / \mathrm{g}$ sediment associated $\mathrm{Zn}$ was measured in enclosed marinas on the south coast of England [12]. During a monitoring campaign at the Port of Calais, Caplat et al. found elevated levels of $\mathrm{Zn}, \mathrm{Cu}, \mathrm{Al}$ and In due to the use of galvanic anodes. At undisturbed-e.g. no dredging activities-sampling points near the anodes up to $371 \mathrm{mg} / \mathrm{kg} \mathrm{Zn}, 56 \mathrm{mg} / \mathrm{kg}$ $\mathrm{Cu}, 49501 \mathrm{mg} / \mathrm{kg} \mathrm{Al}$ and $12.6 \mathrm{mg} / \mathrm{kg}$ In were detected in the sediment [8].

Despite the ubiquitous application of galvanic anodes and the subsequent release of metals, little is known about the consequences for benthic organisms in marine environments. Adverse effects of aluminum anodes were first observed in sea urchin Paracentrotus lividus causing changed fertilization rates and the induction of mitotic abnormalities at concentrations of $3 \mu \mathrm{M}$ and $0.1 \mu \mathrm{M}$ anode-derived $\mathrm{Al}^{3+}$, respectively [13]. In the digestive glands of the mussel Mytilus edulis, an accumulation of up to $1706 \mathrm{mg} / \mathrm{kg}$ Al released from galvanic anodes was observed that was reversible after the transfer of organisms to uncontaminated water [14]. A number of ecotoxicological studies on $\mathrm{Al}$ characterize the impact of acidification on the solubility and release of $\mathrm{Al}$ from e.g. insoluble hydroxides, which might lead to a deterioration of soil and freshwater quality. In this context, a variety of plants and freshwater organisms were examined and showed a broad range of sensitivities depending on $\mathrm{pH}$ and $\mathrm{Al}$ speciation $[15,16]$. In this context, compared to invertebrates, fish have been proven to be particularly sensitive to $\mathrm{Al}$ exposition, in neutral to basic water a no effect concentration of $100 \mu \mathrm{g} / \mathrm{l} \mathrm{Al}$ was reported for trouts. In contrast, marine studies on the ecotoxicological impact of galvanic anodes are scarce [17]. So far, very little attention has been paid to studying the toxicity and accumulation of $\mathrm{Al}$ in benthic organisms. Insoluble and particle-reactive hydroxide $\left(\mathrm{Al}(\mathrm{OH})_{3}\right)$ and aluminate $\left(\left[\mathrm{Al}(\mathrm{OH})_{4}\right]^{-}\right)$species dominate in natural seawater at its common $\mathrm{pH}$ around 8 [18] and could particularly cause a threat to marine sediments and sediment-dwelling organisms. The partitioning of $\mathrm{Al}$ in sediments is dominated by mineral-bound species such as aluminosilicates in feldspars, mica or clays. Leleyter et al. reported a mineral associated content of $\mathrm{Al}$ of 91 to $96 \%$ in various natural sediments and suggested that the labile fraction in turn mainly consists of $\mathrm{Al}$ oxides (95\%) [11, 19].

Unlike $\mathrm{Al}, \mathrm{Zn}$-as the second main component of galvanic anodes-serves as an essential micronutrient, which could become toxic at higher concentrations. Several studies observed toxic effects of $\mathrm{Zn}$ to a variety of organisms such as plants, fish and microorganisms [20-22]. Most recent research pays attention to the toxicity of nanoscale zinc oxide. In this context Wong et al. showed that marine crustaceans were more affected than diatoms and the majority of effects was related to dissolved $\mathrm{Zn}^{2+}$ ions. For the amphipod Elasmopus rapax a half maximal effect concentration of $0.80 \mathrm{mg} / \mathrm{l}$ was determined, whereas the growth of the marine diatom Thalassiosia pseudonana was inhibited to $50 \%$ at $3.48 \mathrm{mg} / \mathrm{l}$ dissolved $\mathrm{Zn}$ [23]. At $\mathrm{pH}$ values around 8 , the free ion $\left(\mathrm{Zn}^{2+}\right)$ and the mononuclear hydroxide $\left([\mathrm{ZnOH}]^{+}\right)$are prevalent in the aqueous phase [24]. If the maximum soluble concentration is exceeded, $\mathrm{Zn}$ can also precipitate as $\mathrm{Zn}(\mathrm{OH})_{2}$ [25]. However, adverse effects of $\mathrm{Zn}$ released from aluminum anodes in the marine environment are mainly expected due to its dissolved species, as $\mathrm{Zn}$ is a minor component in these anodes and local saturation is most likely not reached.

More research is needed to adequately assess the environmental impact of galvanic anodes on the marine environment, in particular with regard to sediment-dwelling marine organisms. Therefore, the main objective of this study was to investigate the acute toxicity of metals released from galvanic aluminum anodes on various trophic levels in the marine environment using the following marine standard test organisms: the sedimentdwelling mud shrimp Corophium volutator, the marine 
diatom Phaeodactylum tricornutum and the luminescent bacterium Aliivibrio fischeri. Besides the acute toxicity testing, a basic uptake experiment using dissolved material from a galvanic anode was carried out at laboratory scale to mimic worst case exposure conditions of sediment-dwelling organisms near offshore installations. Due to the $\mathrm{pH}$-dependent precipitation of aluminum hydroxide after the release of $\mathrm{Al}$ from anodes in seawater, this batch experiment focused on sediment toxicity and a potential uptake of $\mathrm{Al}, \mathrm{Zn}$ and $\mathrm{In}$ by C. volutator.

\section{Methods}

\section{Rationale of exposure scenarios}

Different exposure scenarios for bacteria, algae and amphipods were used because of the following rationale. Bacteria and algae belong to the marine plankton and are most likely exposed to released metal ions that are present in dissolved form under natural conditions. Therefore, only the soluble fraction of the dissolved anode material was used for the exposure of bacteria and algae. Similarly, only the soluble fractions of the ionic $\mathrm{Al}$ and $\mathrm{Zn}$ standards were used for these tests. In case of the dissolved anode material and $\mathrm{Al}$, the assays were performed as limit tests, i.e. exposure at saturation concentration, due to the low solubility of $\mathrm{Al}$ at the $\mathrm{pH}$ of natural sea water. In case of $C$. volutator, the testing was done with the total amount of metal ions, because the sediment dwelling C. volutator is likely to be exposed to both, the dissolved and the precipitated fraction of the metal ions that sediment on the seabed.

\section{Preparation of test solutions}

The natural seawater used in all experiments originated from the amphipod collecting site mentioned in Sect. "Amphipoda". For the testing a stock solution $(10 \mathrm{~g} / \mathrm{l})$ of a commercial galvanic aluminum anode (Al-Zn-In alloy, casted in terms to VG 81257:2009 by Raguse + Voss Metallgießerei GmbH, Germany; $95 \pm 1 \cdot 10^{4} \mathrm{mg} / \mathrm{kg} \mathrm{Al} ; 5 \pm 1 \cdot 10^{4} \mathrm{mg} / \mathrm{kg} \mathrm{Zn}, 203 \pm 1 \mathrm{mg} / \mathrm{kg}$ In) was prepared by dissolving filings of the anode in $30 \%$ $\mathrm{NaOH}$ (w/v) (Merck Suprapur). $\mathrm{Al}^{3+}$ and $\mathrm{Zn}^{2+}$ were used as single element standards (Alfa Aesar Plasma Standard Specpure, $10 \mathrm{~g} / \mathrm{l} \mathrm{Al}$ in $\mathrm{HCl}$; SCP Science PlasmaCAL Custom Standard, $1 \mathrm{~g} / \mathrm{l} \mathrm{Zn}$ in $5 \% \mathrm{HCl}$ ) in the various bioassays for the testing of single elements. Prior to the start of each bioassay, aliquots of the respective metal stock solutions were adjusted to $\mathrm{pH} 8$ with either $30 \% \mathrm{NaOH}(\mathrm{w} / \mathrm{v})$ (Merck Suprapur) or 30\% $\mathrm{HCl}(\mathrm{w} / \mathrm{v})$ (Merck Suprapur, subboiled), resulting in the formation of precipitates. For experiments with the sediment-dwelling amphipods, the saturated solutions with the precipitate were dosed to filtered (Pall VacuCap 90 Filter Unit, $0.45 \mu \mathrm{m}$ ) natural seawater at the desired total bioassay concentration.
In contrast, toxicity testing of $\mathrm{Al}$ and the anode material to algae and luminescent bacteria was designed as a limit test using the maximal seawater soluble metal concentrations at natural $\mathrm{pH}$. For this purpose, the $\mathrm{pH}$ adjusted stock solutions were added to natural seawater in the ratio of 1 to 1000 and stirred for $24 \mathrm{~h}$ until an equilibrium of $\mathrm{Al}$ in the medium was reached (Additional file 1: Fig SI1 and Table SI1). Subsequently, the filtered solution (Nalgene Rapid-Flow Bottle Top Filter with SFCA Membrane, $0.45 \mu \mathrm{m})$ was used for the respective limit test. $\mathrm{ZnCl}_{2}$ (Merck Emsure) with a maximal concentration

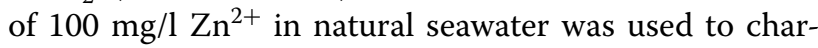
acterize the dose-response relationship of $\mathrm{Zn}$ for algae toxicity. For the testing of bacteria and algae, $\mathrm{Al}$ and $\mathrm{Zn}$ concentrations were measured before the addition of test organisms as well as at the beginning and the end of toxicity testing by ICP-MS.

\section{Bioassays}

\section{Luminescent bacteria}

The bioluminescence inhibition assay was performed according to DIN EN ISO 11348-2 [26] with liquid-dried bacteria (LCK 482, Hach Lange). This standardized test was conducted in glass cuvettes after the reconstitution of the bacteria and measured using a LUMIStox 300 instrument (Hach Lange, Germany). The assay utilizes the bioluminescence of the marine bacterium Aliivibrio fischeri and quantifies the inhibition of the bacterial light emission after exposure to the test sample as a measure for the acute bacterial toxicity. The addition of bacteria to the filtered test solutions reduced the maximal soluble metal concentration in the assay to $80 \%$ of the previously dissolved concentration due to dilution. The initial $\mathrm{Al}$ and $\mathrm{Zn}$ concentrations were analyzed by inductively coupled plasma-mass spectrometry (ICP-MS) as described in Sect. "Chemical Analyses". Each limit test was performed with four replicates for the dissolved aluminum anode as well as the aluminum standard. Every experiment was repeated three times in total. Natural seawater was used as negative control and 3,5-dichlorophenol $(4.5 \mathrm{mg} / \mathrm{l})$ served as the positive control.

\section{Algae}

The growth inhibition test using the marine algae $P$. tricornutum (SAG1090-1a) was based on DIN EN ISO 10253 [27]. The incubation was performed in an incubation shaker (Infors Multitron Pro) at $20^{\circ} \mathrm{C}$ and $120 \mathrm{rpm}$ in polycarbonate Erlenmeyer flasks with a testing volume of $50 \mathrm{ml}$. Test vessels were continuously illuminated with 60-120 $\mu \mathrm{mol}$ photons $/\left(\mathrm{m}^{2} \cdot \mathrm{s}\right)$. To simulate the natural speciation and bioavailability of the investigated metals, tests were conducted in natural seawater at $\mathrm{pH} 8.1$ without the addition of chelating agents or trace metals. 
Merely $15 \mathrm{mg} \mathrm{NO}{ }^{-} / 1$ and $1.5 \mathrm{mg} \mathrm{PO}_{4}{ }^{3-} / 1$ were added to the growth medium to prevent nutrient limitation of algae growth. An exponentially growing pre-culture (up to $10^{4}$ cells $/ \mathrm{ml}$ ) was measured with a fluorescence spectrophotometer (Hitachi F-2500) and adjusted to $5 \times 10^{3}$ cells $/ \mathrm{ml}$. The inoculation of the test solutions diluted the metal concentration in the assay to $80 \%$ of the previously dissolved concentration. $\mathrm{Al}$ and $\mathrm{Zn}$ concentrations were measured at the beginning and the end of the exposure by ICP-MS. Single concentrations of the dissolved aluminum anode and aluminum standard or dilution series of $\mathrm{Zn}$ (test concentration 10 to $1 \mathrm{mg} / \mathrm{l}$ ) were investigated as triplicates. Every experiment was repeated three times in total. Natural seawater was used as negative control and 3,5-dichlorophenol $(2.5 \mathrm{mg} / \mathrm{l})$ served as the positive control. The chlorophyll fluorescence of each sample was determined daily (excitation wavelength $435 \mathrm{~nm}$; emission wavelength $685 \mathrm{~nm}$, plate reader Tecan Infinite M200 Pro). The evaluation of the growth inhibition was performed after $72 \mathrm{~h}$.

\section{Amphipoda}

The DIN EN ISO 16712 standard [28] for the determination of acute toxicity of sediment to amphipods was adapted to study the selected metals. In addition to the classic exposure for 10 days in the presence of sediment, this test was performed according to procedures used for positive controls, i.e. water-only exposures for 3 days, as a worst case scenario reflecting a direct contact of the organisms to the precipitated Al. This exposure was performed under identical conditions and with the same procedural steps except that no sediment was added to the test vessels so that the organisms cannot avoid the exposure to the precipitated metals by digging into the sediment. The test species Corophium volutator had been collected from uncontaminated reference sites at Sylt and Norderney, Germany, respectively. Corresponding sediment and seawater for exposure and control experiments originated from the same collection site (physicochemical characterization ensured consistent sediment and water quality, Additional file 1: Table SI2). The background concentrations in the sediment fractions $<20 \mu \mathrm{m}$ ranged from 48,900 to $60,500 \mathrm{mg} / \mathrm{kg} \mathrm{Al}$ and from 150 to $221 \mathrm{mg} / \mathrm{kg}$ $\mathrm{Zn}$. The dissolved amount of $\mathrm{Al}$ and $\mathrm{Zn}$ in seawater was always below the limit of quantification $(0.02 \mathrm{mg} / \mathrm{l} \mathrm{Al}$ and $0.11 \mathrm{mg} / \mathrm{l} \mathrm{Zn}$ ). The sediment was sieved through a $1 \mathrm{~mm}$ screen prior usage to remove native macroorganisms. Accordingly, the seawater was filtered to $0.45 \mu \mathrm{m}$ (Pall VacuCap 90 Filter Unit). After acclimatization to laboratory conditions, 20 individuals were added to 11 beakers filled with 300 g sediment (approx.
$2 \mathrm{~cm}$ depth) and $700 \mathrm{~g}$ test solution or $900 \mathrm{~g}$ test solution without sediment. The incubation was performed under constant aeration and lighting at $15{ }^{\circ} \mathrm{C}$. At the end of respective testing periods, the content of test vessels was sieved and living organisms were counted. $\mathrm{Al}$ and the dissolved aluminum anode were investigated at nominal concentrations of 1,10 and $100 \mathrm{mg} /$ $\mathrm{kg}$ seawater. The toxicity of $\mathrm{Zn}$ was characterized at nominal concentrations of $0.1,1$ and $10 \mathrm{mg} / \mathrm{kg}$ seawater. Nominally dosed concentrations in this bioassay were not accompanied by chemical analyses of seawater. Two to six independent replicates were tested for each concentration level and exposure type (with and without sediment). Each experiment accompanied by negative controls with only seawater (with and without sediment). To assess the sensitivity of the test populations, ammonium chloride $\left(30-150 \mathrm{mg} / \mathrm{l} \mathrm{NH}_{4}{ }^{+}\right.$) served as reference toxicant (without sediment).

\section{Uptake of metals by Corophium volutator}

The possible uptake of metals from galvanic anodes was investigated using C. volutator. As toxicity tests with C. volutator according to DIN EN ISO 16712 [28] provided not enough sample material for chemical analysis, the experimental set up was scaled up from 11 beakers to $5 \mathrm{l}$ aquariums with about 200 individuals per tested exposure concentration. All other test parameters, such as concentration levels and exposure time, remained the same. More specifically, the investigations were carried out in presence and absence of sediment and at nominal concentrations of 1,10 and $100 \mathrm{mg}$ dissolved aluminum anode per $\mathrm{kg}$ seawater. Due to the high amount of mud shrimp required for analysis in this basic uptake experiment, exposure was not carried out in replicate. At the end of the testing period, test organisms were kept for at least $1 \mathrm{~h}$ in fresh seawater for gut purging and were subsequently anaesthetized by aeration with $\mathrm{CO}_{2}$. The gut passage time of sediment for C. volutator was previously verified on multiple individuals by the observation under a stereomicroscope. Preliminary tests showed that precipitates adhere to plumose setae (i.e., the hair-like structures of the pereiopods and the pleopods of the test organisms). Thus, attached particles had to be removed prior to the determination of metal accumulation by ICP-MS to prevent an overestimation of metal contents. After wash conditions had been optimized (Additional file 1: Fig SI2 and Table SI3), exposed organisms were washed with $0.5 \% \mathrm{HNO}_{3}$ under agitation at $250 \mathrm{rpm}$ for $30 \mathrm{~min}$ to ensure sufficient removal of attached material. Subsequently, organisms were rinsed with ultrapure water, shock frozen in liquid nitrogen, freeze-dried 
and homogenized for $1 \mathrm{~min}$ at $20 \mathrm{~Hz}$ with a mixer mill (Retsch M400).

\section{Statistical analysis}

The statistical analysis of bioassay data was performed with the open source software R using the core distribution, version 3.4.3 and R-Studio, version 1.1.383.

After checking for normal distribution with Shapiro-Wilk's test and homoscedasticity with F-test, an unpaired, two-sided t-test (normally distributed, homoscedastic data), Welch's t-test (normally distributed, not homoscedastic data) or Mann-Whitney U test (data not normally distributed) was used to determine statistical differences in ecotoxicological effects. In case of statistically significant differences in $\mathrm{t}$-test, the strength was calculated. All tests were performed at the significance level $\alpha=0.05$.

The fit of concentration-response relationships and the estimate of the half maximal effective concentration (EC50) were calculated by a five-parameter log-logistic function (Eq. 1) by means of the extension package $d r c$ (version 3.0.1) [29].

$$
\boldsymbol{f}(\boldsymbol{x})=\boldsymbol{c}+\frac{\boldsymbol{d}-\boldsymbol{c}}{(1+\exp (\boldsymbol{b} \times(\log (\boldsymbol{x})-\log (\boldsymbol{e}))))^{\boldsymbol{f}}} .
$$

The response is evaluated as a function of the concentration $x$ with the parameters $c$ and $d$ as lower and upper response limits, respectively. The parameter $e$ is defined as inflection point, parameter $b$ denotes the relative slope and the parameter $f$ describes the asymmetry of the curve.

\section{Chemical analyses}

$\mathrm{Al}, \mathrm{Zn}$ and In concentrations in seawater samples were analyzed by ICP-MS (7700 ICP-MS, Agilent Technologies, Inc., USA) according to Düster et al. [30]. Samples were diluted at least 1:10 to reduce salt concentrations and thus matrix load. If analyte concentrations exceeded the linear range of the calibrated system (i.e., $>200 \mu \mathrm{g} / \mathrm{l}$ ), samples were diluted. All samples were analyzed as triplicates and mean values were provided for statistical analysis. The following reference materials were used for method validation: SPS-SW1, SPS-SW2 (Spectrapure Standards, Norway) and SRM 1640a (NIST, USA).

Prior to the analysis of $\mathrm{Al}, \mathrm{Zn}$ and In in the bulk of $C$. volutator by ICP-MS, amphipods were dissolved using microwave pressure digestion (turboWave, MLS GmbH, Germany) as summarized in Additional file 1: Table SI4. For the digestion $50 \mathrm{mg}$ of freeze-dried, ground and homogenized amphipods, $0.6 \mathrm{ml} \mathrm{HNO}_{3}$ (65\%, Suprapur, subboiled, Merck KGaA, Germany) and $0.4 \mathrm{ml} \mathrm{HCl}$ (30\%, Suprapur, subboiled, Merck KGaA, Germany) were used. All samples were digested in triplicate and analyzed as described above. In addition, NCS ZC73034 (China National Analysis Center for Iron \& Steel, China), a prawn standard, and SRM 2976 (NIST, USA), a mussel tissue standard, were digested and measured as reference materials. All procedures were optimized to obtain a recovery of $100 \pm 10 \%$ for the analytes in the reference material.

\section{Results}

\section{Acute toxicity}

In case of testing with A. fischeri, no significant effects were detected for any of the tested materials (Additional file 1: Table SI5). In case of P. tricornutum, the dissolved anode and $\mathrm{Al}$ at saturation concentration at $\mathrm{pH}=8.1$ caused a comparable and statistically significant decrease of the growth rate (Fig. 1 and Additional file 1: Table SI6) with an average growth inhibition of $28.3 \pm 6.3 \%$ and $26.0 \pm 2.6 \%$, respectively. The mean exposure concentration of $\mathrm{Al}$ from the dissolved anode material was $818 \pm 19 \mu \mathrm{g} / \mathrm{l}(824 \mu \mathrm{g} / \mathrm{l}$ at the beginning and $817 \mu \mathrm{g} / \mathrm{l}$ at the end of exposure), while the determined concentrations of zinc and indium were below their respective detection limits of $32 \mu \mathrm{g} / \mathrm{l}$ and $29 \mu \mathrm{g} / \mathrm{l}$ in seawater. When tested as a single element, the mean exposure concentration of $\mathrm{Al}$ was $880 \pm 24 \mu \mathrm{g} / \mathrm{l}(899 \mu \mathrm{g} / \mathrm{l}$ at the beginning and $874 \mu \mathrm{g} / \mathrm{l}$ at the end of exposure). Additionally, the effect of $\mathrm{Zn}$ on algal growth was characterized as a concentration-response curve at dissolved concentrations from 0.9 up to $8 \mathrm{mg} / \mathrm{l}$ (Fig. 2 and Additional file 1:

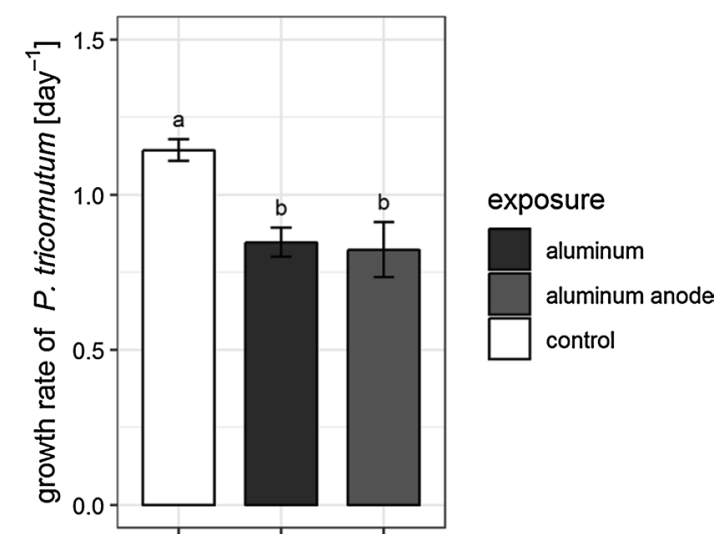

Fig. 1 Average growth rate of $P$. tricornutum during limit testing of aluminum and the aluminum anode. Diatoms were exposed for $72 \mathrm{~h}$ to maximum soluble metal concentrations $(n=3$, error bars indicate SE) under natural seawater $\mathrm{pH}$ conditions. Significantly different means are marked with different letters (two-tailed unpaired t-test, $p<0.05$ ) 
Table SI8). Applied metal concentrations quantified by ICP-MS are summarized in Additional file 1: Tables SI7 and SI9. Higher concentrations could not be tested without decreasing the $\mathrm{pH}$ value of the medium. Under $\mathrm{pH}$ conditions of the investigated natural seawater, the EC50 of $\mathrm{Zn}^{2+}$ for P. tricornutum was determined as $5.70 \pm 0.33 \mathrm{mg} / \mathrm{l}$ (with a fixed maximum growth inhibition of $100 \%)$.

In case of $C$. volutator, the investigated anode material caused no acute toxicity. However, the single elements

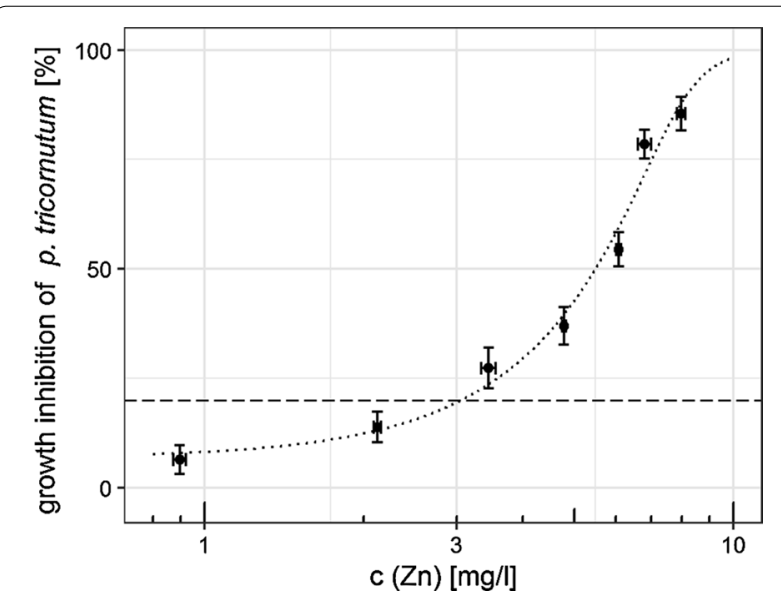

Fig. 2 Concentration-dependent growth inhibition of $P$. tricornutum during zinc exposure for $72 \mathrm{~h}$ ( $m e a n \pm S E, n=3$ ). The dashed line indicates 20\% effect level and dotted line shows 5 -parametric log-logistic fit of data $(b=-10.3, c=6.8, d=100, e=7.99, f=0.20$; Eq. 1)
$\mathrm{Al}$ and $\mathrm{Zn}$ showed significant effects at the highest tested concentrations $(100 \mathrm{mg} / \mathrm{kg}$ aluminum, $10 \mathrm{mg} / \mathrm{kg}$ zinc) as illustrated in Fig. 3 and Additional file 1: Table SI10. In case of $\mathrm{Al}$, experiments in the absence of sediments exhibited higher effects on C. volutator mortality (max. mortality of $17.5 \pm 4.2 \%$ ) compared to exposure in the presence of sediment. On the contrary, $\mathrm{Zn}$ caused the highest mortality of $C$. volutator $(52.5 \pm 7.5 \%)$ in the presence of sediment. In the absence of sediment, the mortality was $30 \pm 5.4 \%$. Statistically significant differences between exposures with and without sediments were only detected in case of the exposition with $100 \mathrm{mg} /$ $\mathrm{kg}$ aluminum (two-tailed, unpaired Mann-Whitney U test, $\mathrm{p}=0.017)$.

\section{Uptake of metals}

To study the potential uptake of the three components $\mathrm{Al}, \mathrm{Zn}$ and In of galvanic aluminum anodes, concentrations of these metals were determined in C. volutator after exposure to dissolved galvanic anode material in the presence and absence of sediment, respectively. The results are shown in Figs. 4, 5 and Additional file 1: Table SI12 and Table SI13. No increase of residual metal content compared to the control group was observed in $C$. volutator in the experiments with sediment. In contrast, all investigated elements revealed increased concentrations in C. volutator after exposure without sediment. The extent of accumulation indicated differences among the studied metals. As expected, given its prevalence in the dissolved galvanic anode solution, $\mathrm{Al}$ showed the
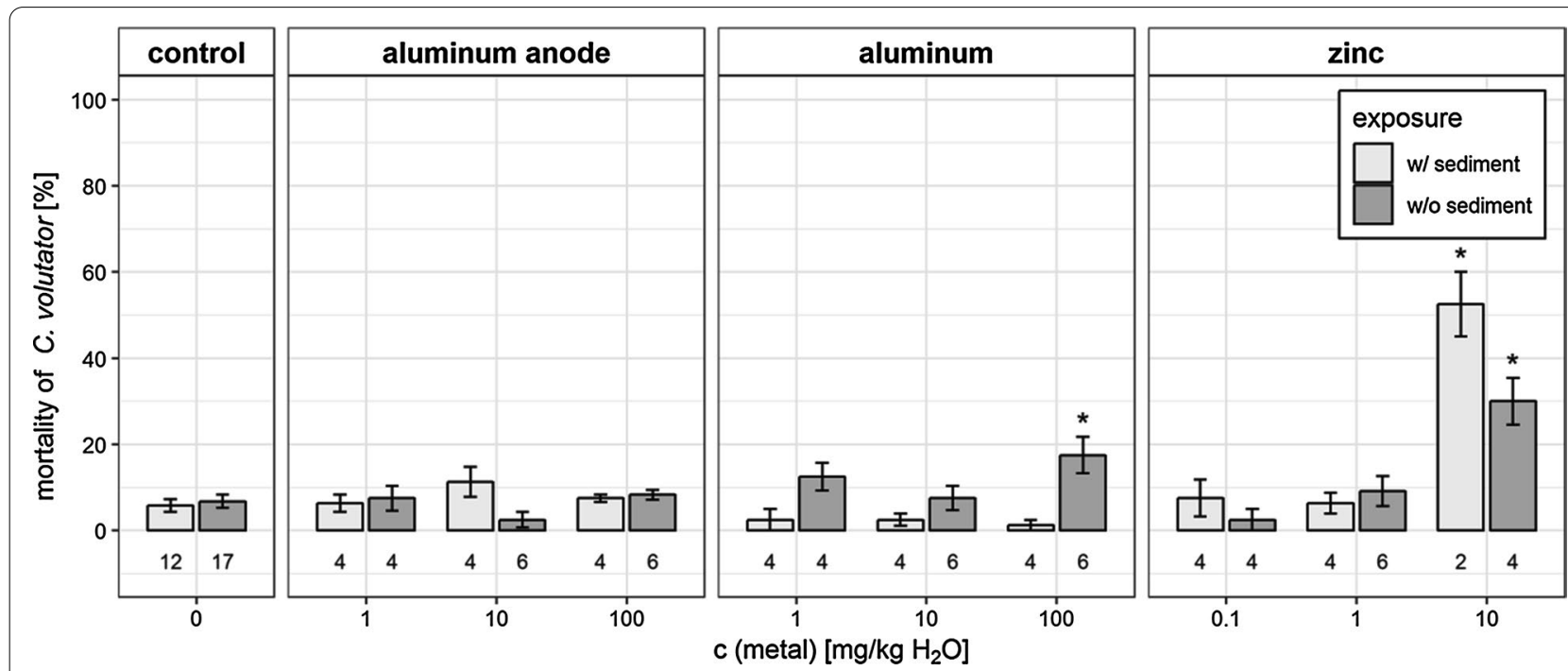

Fig. 3 Average toxicity ( \pm SE) caused by the dissolved galvanic anode and its main components aluminum and zinc to $C$. volutator. Test organisms were exposed to the different metal concentrations for ten days with $(\mathrm{w} /$ ) sediment and 3 days without $(\mathrm{w} / \mathrm{O})$ sediment. The numbers below the bars represent the number of replicates of each experiment. Experiments with statistically significant differences to the corresponding negative control are marked with an asterisk (two-tailed unpaired t-test, $p<0.01$ ). See Additional file 1: Table SI11 for complete data of statistical evaluation 

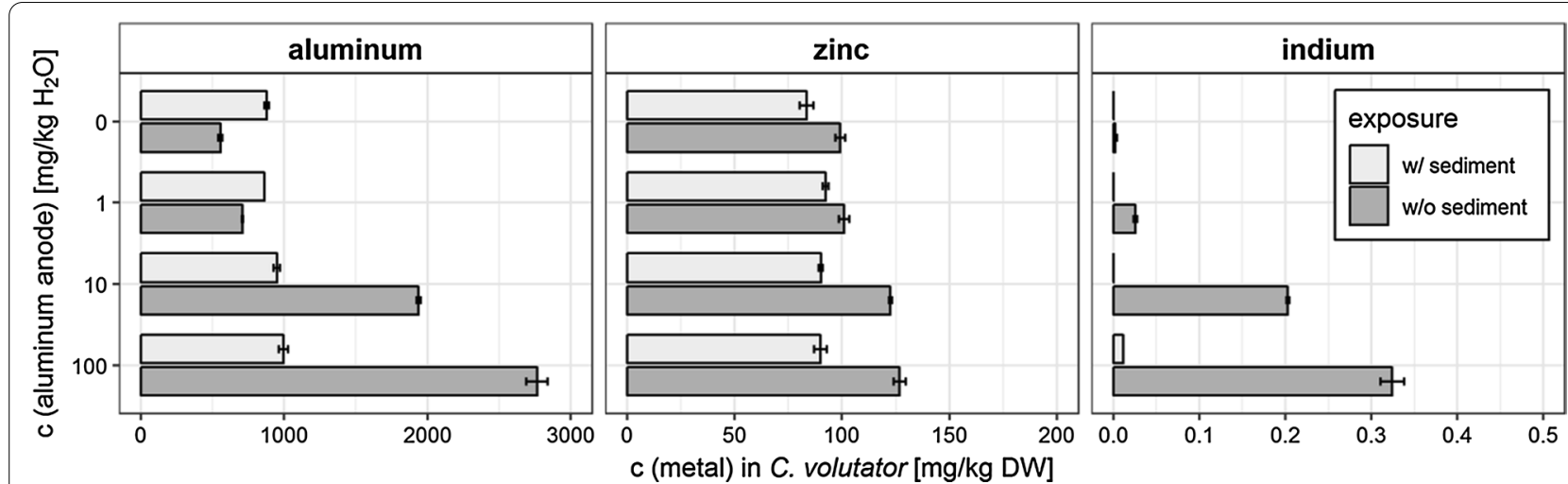

Fig. 4 Average $\mathrm{Al}, \mathrm{Zn}$ and In concentrations ( \pm SE of technical triplicates) in C. volutator. The exposure with the dissolved aluminum anode proceeded for 10 days with sediment and three days without sediment. At the end of the testing period, the organisms were washed with $0.5 \%$ $\mathrm{HNO}_{3}$ for 30 min to remove adherent metal precipitates from exoskeleton, freeze-dried, homogenized, digested and subsequently analyzed by ICP-MS

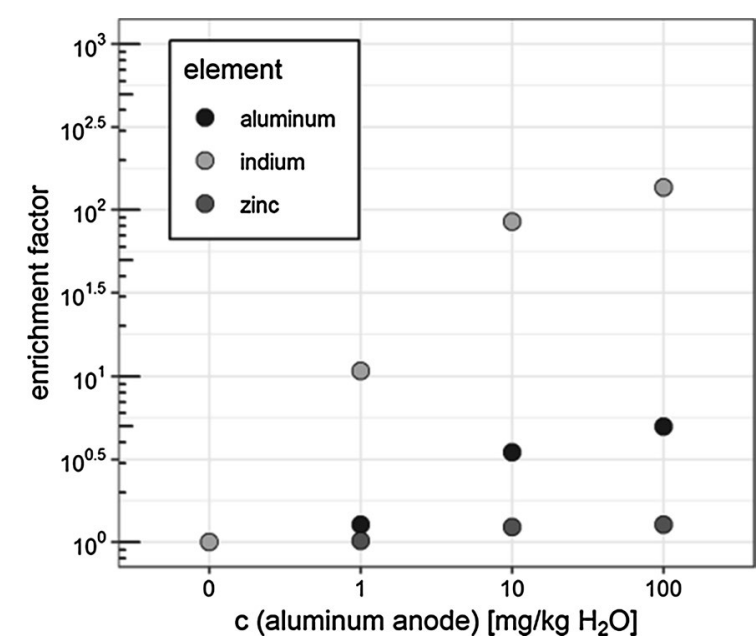

Fig. 5 Enrichment factor in C. volutator after exposure to dissolved aluminum anode material. Results are shown for the exposure with three different concentrations for 3 days in the absence of sediment. Analyte residue concentrations are based on dry weight of organisms. The enrichment factor represents the ratio of analyte residues detected in exposed compared to non-exposed organisms

highest concentrations in the mud shrimp after exposure. Concentration increased up to $2,200 \mathrm{mg} / \mathrm{kg}$ dry weight, which resulted in $\mathrm{Al}$ levels five times above those in the unexposed control group.

Although In represents a minor constituent of the tested galvanic anode, it showed the highest relative enrichment in mud shrimp. At the highest exposure level, the measured In concentration in $C$. volutator increased 136-fold compared to the negative control. The lowest enrichment was found for $\mathrm{Zn}$. The $\mathrm{Zn}$ concentration in the test organisms was elevated by approximately $28 \%$ at the highest exposure level compared to the negative control. In summary, dissolved galvanic anode concentrations in seawater showed a positive correlation with residual metal concentration in biota. However, enrichment expressed no linear relationship in terms of applied test concentration of the dissolved galvanic anode. Nevertheless, the highest enrichment was observed at the highest exposure concentration (Fig. 5).

\section{Discussion}

In order to assess potential ecotoxicological risks, a worst case exposure of three marine organisms from different trophic levels, i.e. the marine algae $P$. tricornutum, the bacterium A. fischeri and the amphipod C. volutator was performed for aluminum, zinc and the dissolved galvanic anode. For P. tricornutum, an EC50 value for zinc of about $42 \mathrm{mg} / \mathrm{l}$ for exponentially growing algae in $\mathrm{f} / 2$ medium was reported [31]. The respective EC50 value of $5.34 \mathrm{mg} / \mathrm{l}$ determined in the present study is eightfold lower. In contrast to the EC50 previously published, no further compounds such as vitamins and other trace metals that are present in the $f / 2$ medium were added to the current experiments to achieve effect data under most realistic conditions. These differences might explain the higher $\mathrm{Zn}$ sensitivity for P. tricornutum reported here in comparison to previous studies. Deborde et al. reported a maximum increase of dissolved $\mathrm{Zn}$ content to around $200 \mu \mathrm{g} / \mathrm{l}$ during the anode activation period in a tank experiment [9]. Based on the $20 \%$ effect concentration (EC20, around $3 \mathrm{mg} / \mathrm{l}$ ) as an estimate for the boundary between the lowest and no observed effect concentration (LOEC and NOEC), the resulting risk quotient is about 0.07 , which indicates that there is no acute risk for P. tricornutum from the use of galvanic anodes in marine environments. In comparison to the freshwater green 
algae Pseudokirchneriella subcapitata, the marine algae P. tricornutum seems to be more tolerant for $\mathrm{Zn}^{2+}$. The reported EC50 for growth inhibition of the freshwater algae at $\mathrm{pH}=7.5$ is $16.3 \mu \mathrm{g} / \mathrm{l}$ [32].

The observed growth inhibition of $P$. tricornutum at $\mathrm{Al}$ concentrations around $850 \mu \mathrm{g} / \mathrm{l}$ is in agreement with Gillmore et al., who reported an EC10 of $920 \mu \mathrm{g} / \mathrm{l}$ for growth inhibition of the same algae under similar conditions [33]. During the anodic dissolution in a tank experiment, Deborde et al. measured dissolved aluminum concentrations of 0.2 to $0.5 \mu \mathrm{g} / \mathrm{l}$, which was in the range of the natural background concentration [9]. Thus, effects on growth of marine algae caused by $\mathrm{Al}$ seem unlikely. The same conclusion was drawn by Zhou et al., who reviewed the aluminum toxicity to marine phytoplankton [17]. However, Gillmore et al. showed that diatoms with higher silicon content in cell walls are more sensitive [33]. For Ceratoneis closterium and Minutocellus polymorphus a $10 \%$ inhibition of the growth rate was observed already at $\mathrm{Al}$ concentrations of 69 and $440 \mu \mathrm{g} / \mathrm{l}$, respectively. Based on these numbers, a growth inhibition of $C$. closterium might occur in close proximity to the galvanic anodes when the released aluminum is not yet further diluted by the surrounding water. The presented results indicate furthermore that the inhibition of algae growth by the dissolved galvanic anode reported in the current study is mainly caused by aluminum, as the observed effects do not differ significantly between the exposure to the dissolved galvanic anode and aluminum alone. Thus, possible mixture effects of metals released from a galvanic anode on the growth of $P$. tricornutum are unlikely.

No acute toxicity for any of the tested materials was observed for A. fischeri, indicating a lower toxicity of metals released from galvanic anodes for marine bacteria compared to algae. However, due to the scarcity of literature about $\mathrm{Al}$ toxicity on bacteria, it is challenging to extrapolate this finding to the field. A varying sensitivity for other marine bacteria is to be expected. In this respect, it is interesting that recent studies have shown that aluminum can even have a stimulative effect on the growth of different cyanobacteria [34, 35]. Nevertheless, it can be concluded that bacterial toxicity is unlikely to be the main driver for an environmental risk assessment of galvanic anodes because species from other trophic levels showed higher sensitivities.

Corophium volutator showed only a significantly increased mortality at nominal $\mathrm{Al}$ concentrations of $100 \mathrm{mg} / \mathrm{l}$ in the exposure without sediment. Although not directly indicated by a comparison of the mortality in the controls with and without sediment, the toxicity observed in the absence of sediment might be caused by a higher general stress level of the organisms when exposed solely in water. A further explanation might be the possibility for the organisms to avoid the exposure to the precipitated $\mathrm{Al}(\mathrm{OH})_{3}$ after digging into the sediment or absorption of the element to the sediment. This observation suggests a protective function of the sediment for benthic organisms. Furthermore, toxic $\mathrm{Al}^{3+}$ ions might be sequestered by the sediment lowering the bioavailability of $\mathrm{Al}$ for the exposed organisms. On the other hand a saturated $\mathrm{Al}$ concentration might be expected because of the precipitated $\mathrm{Al}(\mathrm{OH})_{3}$ that can replenish the $\mathrm{Al}$ aquo complexes in solution. The formation of colloidal $\mathrm{Al}(\mathrm{OH})_{3}$ and various polymeric $\mathrm{Al}(\mathrm{III})$ cations in dependence of the surrounding $\mathrm{pH}$ is challenging for the assessment of the bioavailability of $\mathrm{Al}$ species. The chronic toxicity of aluminum to freshwater organisms was successfully predicted by multiple linear regression [36] and a biotic ligand model [37]. However, a valid model is currently not available for marine ecosystems.

In case of $\mathrm{Zn}$, a reduction of toxicity due to the presence of sediment was reported by Bat et al., the EC50 values for $\mathrm{Zn}$-induced mortality of $C$. volutator was $14.12 \mathrm{mg} / \mathrm{l}$ in the presence and $9.79 \mathrm{mg} / \mathrm{l}$ in the absence of sediment [38]. Although exposure times differed between the published (four days for both setups) and the current experiments, the values for the observed mortality are in good agreement with the previous study (about $50 \%$ mortality at $10 \mathrm{mg} / \mathrm{l}$ zinc). The comparatively higher toxicity for exposure in the presence of sediment in the current work might be explained by the longer exposure times for this setup compared to the earlier report. Concentrations of total Zn during the anode activation period in a tank experiment ranged from 28.3 to $360.0 \mu \mathrm{g} / \mathrm{l}$ [9]. Under consideration of this maximum release and a roughly estimated NOEC of $1 \mathrm{mg} / \mathrm{l}$, the risk quotient for zinc ranges from 0.03 to 0.36 . Conradi \& Depledge reported values for chronic $\mathrm{Zn}$ exposure in sediment over up to 107 days [39]. They found a significantly decreased survival at $\mathrm{Zn}$ concentrations of $800 \mu \mathrm{g} / \mathrm{l}$, which is more than two times above the highest $\mathrm{Zn}$ concentration determined during the tank experiments of Deborde et al. [9].

To assess the potential uptake of the metals by $C$. volutator, the metal composition with respect to aluminum, zinc and indium of this organism was analyzed before and after exposure to the three different concentrations of the dissolved galvanic anode. Interestingly, the maximum enrichment factor of the three metals in biota reflects the ratio between the metal content in the galvanic anode and the natural biota-level of the metals in the mud shrimp. If normalized to $\mathrm{Zn}=1$, the ratio between metal concentrations in the galvanic anode and the non-exposed shrimp was 3.4 for aluminum and 170 for indium. This corresponds well to the normalized maximum enrichment factor of 3.8 for aluminum and about 105 for indium. In other words, the 
metal composition in biota after the exposure reflects the metal composition of the galvanic anode indicating that there is no specific mechanism in C. volutator that would favor the uptake of one of the investigated elements over the other. The uptake of potentially toxic metals by aquatic organisms can take place in general across the integument, through the respiratory surfaces (e.g. gills), or the gut after ingestion of contaminated food [40]. The mud shrimp C. volutator, due to its filter and deposit feeding activity, is exposed to the particular risk of particle-associated contaminants and therefore the uptake of metals from precipitates in the current experiments. Analysis of the exposed organisms provided valuable additional information but raised the question, where the enriched elements are located, i.e., in or at the organism. As Rainbow \& Luoma described, metal toxicity is not necessarily related to the total accumulated amount in the organism, because the metals are frequently stored in detoxified forms [41]. The removal of metals from cytoplasm by complexation and accumulation in spherical precipitates in membrane bound vesicles or vacuoles is a well-known detoxification strategy of crustaceans [40]. The same applies to $C$. volutator, where e.g. zinc-rich granules could be observed in hepatopancreas [42]. Alternatively, the elements released by the galvanic anode might be absorbed at the shell of the crustacea. In fact, the biosorption of various metal ions to chitin is used as an approach to purify water from e.g. mining sites [43, 44]. It has been demonstrated that chitin can remove metal ions from aqueous solutions by adsorption to functional groups such as hydroxyl- and amino-residues [45, 46]. Based on modeling results, Tarpani et al. proposed chemisorption of $\mathrm{Al}^{3+}$ to chitin [44]. A strong binding of metal ions to chitin might explain why the elements were detected in elevated levels despite the acidic washing step. However, the bulk analysis of exposed organisms alone provides no further information. To elucidate the localization of the accumulated metals, methods allowing a special analysis such as laser ablation ICP-MS [47-49] should be applied. The reported enrichment of metal ions by C. volutator-either due to uptake or adsorption-might promote a trophic transfer in the marine environment. Benthic invertebrates usually serve as food for larger invertebrates, fish and also birds. As previously reported, aluminum in freshwater can be transferred from a primary to a secondary consumer [50]. In particular with respect to the potential use of areas surrounding offshore wind farms for aquaculture [51, 52], further studies are required to investigate the direct and indirect uptake of metals released from galvanic anodes by marine organisms for a risk assessment on environment and human health.

\section{Conclusion}

Based on the assessment of the acute toxicity to three organisms of different trophic levels, a direct environmental threat by the use of galvanic anodes for cathodic protection of wind turbine support structures in the marine environment was not indicated. Toxicity thresholds for C. volutator, A. fischeri and P. tricornutum determined in worst case exposure scenarios were in most cases at least one order of magnitude higher compared to the concentrations of aluminum and zinc that are expected to be released during cathodic protection. However, a growth inhibition of marine algae in close proximity to an operating galvanic anode might occur if the dilution of the released metal ions occurs by diffusion only. The observed accumulation of aluminum and indium in crustacea might facilitate their enhanced entry into the food chain. To develop a broader picture of the environmental impact of galvanic anodes in marine environments, future investigations should be extended to higher trophic levels, the potential trophic transfer of respective metals and possibly more sensitive chronic endpoints. If sublethal or developmental assays resulted in more significant effects, also the investigation of mixture toxicity could be useful extension of the presented work.

\section{Supplementary information}

Supplementary information accompanies this paper at https://doi. org/10.1186/s12302-020-00441-3.

Additional file 1: Tables and Figures.

\section{Abbreviations}

Al: Aluminum; EC20: 20\% effect concentration; EC50: Half maximal effective concentration; ICP-MS: Inductively coupled plasma-mass spectrometry; In: Indium; LOEC: Lowest observed effect concentration; NOEC: No observed effect concentration; Zn: Zinc.

\section{Acknowledgements}

The authors thank Emily Fischer for technical assistance with ICP-MS analyses.

\section{Authors' contributions}

$\mathrm{BM}$ and TT formulated the overarching research goals and aims. AMB and SB conceived and designed this study. AMB and MvdA coordinated and conducted the experiments. The data analysis and visualization were performed by $\mathrm{AMB}$ and SB. All authors contributed to the discussion and interpretation of results. The manuscript was drafted by $A M B, M v d A$ and $S B$ and revised by all authors. All authors read and approved the final manuscript.

\section{Funding}

Open Access funding enabled and organized by Projekt DEAL. The project was funded within the governmental research and development-budget of the German Federal Ministry of Transport and Digital Infrastructure (BMVI). 


\section{Availability of data and materials}

All data generated or analyzed during this study are included in this published article and its supplementary information file.

\section{Ethics approval and consent to participate}

Not applicable.

\section{Consent for publication}

Not applicable.

\section{Competing interests}

The authors declare that they have no competing interests.

\section{Author details}

${ }^{1}$ Department G3 - Biochemistry, Federal Institute of Hydrology, Ecotoxicology, Am Mainzer Tor 1, Koblenz 56068, Germany. ${ }^{2}$ Department G2 - Aquatic Chemistry, Federal Institute of Hydrology, Am Mainzer Tor 1, Koblenz 56068, Germany. ${ }^{3}$ Section B2 - Steel Structures and Corrosion Protection, Federal Waterways Engineering and Research Institute, Kußmaulstr. 17, Karlsruhe 76187, Germany. ${ }^{4}$ Division 1.1 - Inorganic Trace Analysis, Federal Institute for Materials Research and Testing, Richard-Willstätter-Str. 11, Berlin 12489, Germany.

Received: 14 September 2020 Accepted: 30 November 2020

Published online: 14 December 2020

\section{References}

1. DNV (2017) Recommended practice DNVGL-RP-B401: Cathodic protection design

2. DIN (2014) Galvanic Anodes for cathodic protection in seawater and saline mud. https://doi.org/10.31030/2088472

3. Szabo S, Bakos I (2006) Cathodic protection with sacrificial anodes. Corros Rev 24(3-4):231-280

4. European Commission (2018). A Clean Planet for all - A European strategic long-term vision for a prosperous, modern, competitive and climate neutral economy

5. WindEurope (2019) Offshore Wind in Europe - Key trends and Statistics. https://windeurope.org/wp-content/uploads/files/about-wind/statistics/ WindEurope-Annual-Offshore-Statistics-2019.pdf

6. HTG (2009) Kathodischer Korrosionsschutz im Wasserbau. https://www htg-online.de/fileadmin/dateien/FA/FA_Korrosionsfragen/HTG-Handb uch_Dezember_2009_Korrektur_mit_Titelseite.pdf

7. Kirchgeorg T, Weinberg I, Hörnig M, Baier R, Schmid M, Brockmeyer B (2018) Emissions from corrosion protection systems of offshore wind farms: evaluation of the potential impact on the marine environment. Mar Pollut Bull 136:257-268. https://doi.org/10.1016/j.marpo Ibul.2018.08.058

8. Caplat C, Basuyaux O, Pineau S, Deborde J, Grolleau AM, Leglatin S, Mahaut ML (2019) Transfer of elements released by aluminum galvanic anodes in a marine sedimentary compartment after long-term monitoring in harbor and laboratory environments. Chemosphere 239:124720. https://doi.org/10.1016/j.chemosphere.2019.124720

9. Deborde J, Refait P, Bustamante P, Caplat C, Basuyaux O, Grolleau AM, Mahaut ML, Brach-Papa C, Gonzalez JL, Pineau S (2015) Impact of galvanic anode dissolution on metal trace element concentrations in marine waters. Water Air Soil Pollut 226(12):14. https://doi.org/10.1007/s1127 0-015-2694-x

10. Gabelle C, Baraud F, Biree L, Gouali S, Hamdoun H, Rousseau C, van Veen $E$, Leleyter $L$ (2012) The impact of aluminium sacrificial anodes on the marine environment: a case study. Appl Geochem 27(10):2088-2095. https://doi.org/10.1016/j.apgeochem.2012.07.001

11. Leleyter L, Baraud F, Reinert T, Gouali S, Lemoine M, Gil O (2018) Fate of aluminium released by sacrificial anodes - Contamination of marine sediments by environmentally available compounds. C R Geosci 350(5):195201. https://doi.org/10.1016/j.crte.2018.05.003

12. Bird P, Comber SDW, Gardner MJ, Ravenscroft JE (1996) Zinc inputs to coastal waters from sacrificial anodes. Sci Total Environ 181(3):257-264. https://doi.org/10.1016/0048-9697(95)05025-6

13. Caplat C, Oral R, Mahaut ML, Mao A, Barillier D, Guida M, Della Rocca C, Pagano G (2010) Comparative toxicities of aluminum and zinc from sacrificial anodes or from sulfate salt in sea urchin embryos and sperm. Ecotoxicol Environ Saf 73(6):1138-1143. https://doi.org/10.1016/j.ecoen v.2010.06.024

14. Mao A, Mahaut M-L, Pineau S, Barillier D, Caplat C (2011) Assessment of sacrificial anode impact by aluminum accumulation in mussel Mytilus edulis: a large-scale laboratory test. Mar Pollut Bull 62(12):2707-2713. https://doi.org/10.1016/j.marpolbul.2011.09.017

15. Gensemer RW, Playle RC (1999) The bioavailability and toxicity of aluminum in aquatic environments. Critical Rev Environmental Sci Technol 29(4):315-450. https://doi.org/10.1080/10643389991259245

16. Singh S, Tripathi DK, Singh S, Sharma S, Dubey NK, Chauhan DK, Vaculik M (2017) Toxicity of aluminium on various levels of plant cells and organism: a review. Environ Exp Bot 137:177-193. https://doi.org/10.1016/j.envex pbot.2017.01.005

17. Zhou LB, Tan YH, Huang LM, Fortin C, Campbell PGC (2018) Aluminum effects on marine phytoplankton: implications for a revised Iron Hypothesis (Iron-Aluminum Hypothesis). Biogeochemistry 139(2):123-137. https ://doi.org/10.1007/s10533-018-0458-6

18. Tria J, Butler ECV, Haddad PR, Bowie AR (2007) Determination of aluminium in natural water samples. Anal Chim Acta 588(2):153-165. https ://doi.org/10.1016/j.aca.200'1.02.048

19. Leleyter L, Probst JL (1999) A new sequential extraction procedure for the speciation of particulate trace elements in river sediments. Int J Environ Anal Chem 73(2):109-128. https://doi.org/10.1080/03067319908032656

20. Admiraal W, Blanck H, Buckert-De Jong M, Guasch $H$, Ivorra N, Lehmann V, Nystrom BAH, Paulsson M, Sabater S (1999) Short-term toxicity of zinc to microbenthic algae and bacteria in a metal polluted stream. Water Res 33(9):1989-1996. https://doi.org/10.1016/s0043-1354(98)00426-6

21. De Schamphelaere KAC, Janssen CR (2004) Bioavailability and chronic toxicity of zinc to juvenile rainbow trout (Oncorhynchus mykiss): comparison with other fish species and development of a biotic ligand model. Environ Sci Technol 38(23):6201-6209. https://doi.org/10.1021/ es049720m

22. Rout GR, Das P (2003) Effect of metal toxicity on plant growth and metabolism: i. Zinc. Agronomie 23(1):3-11. https://doi.org/10.1051/agro:20020

23. Wong SWY, Leung PTY, Djurisic AB, Leung KMY (2010) Toxicities of nano zinc oxide to five marine organisms: influences of aggregate size and ion solubility. Anal Bioanal Chem 396(2):609-618. https://doi.org/10.1007/ s00216-009-3249-z

24. Reichle RA, McCurdy KG, Hepler LG (1975) Zinc hydroxide: solubility product and hydroxy-complex stability constants from 12.5-75 C. Canadian Journal of Chemistry 53 (24):3841-3845

25. Jelmert A, van Leeuwen J (2000) Harming local species or preventing the transfer of exotics? Possible negative and positive effects of using zinc anodes for corrosion protection of ballast water tanks. Water Res 34(6):1937-1940. https://doi.org/10.1016/s0043-1354(99)00416-9

26. ISO (2007) Water quality - Determination of the inhibitory effect of water samples on the light emission of Vibrio fischeri (Luminescent bacteria test) - Part 2: Method using liquid-dried bacteria

27. ISO (2018) Water quality - Marine algal growth inhibition test with Skeletonema costatum and Phaeodactylum tricomutum

28. ISO (2007) Water quality - Determination of acute toxicity of marine or estuarine sediment to amphipods

29. Ritz C, Baty F, Streibig JC, Gerhard D (2015) Dose-Response Analysis Using R. PLoS ONE 10(12):13. https://doi.org/10.1371/journal.pone.0146021

30. Duester L, Wahrendorf DS, Brinkmann C, Fabricius AL, Meermann B, Pelzer J, Ecker D, Renner M, Schmid H, Ternes TA, Heininger P (2017) A framework to evaluate the impact of armourstones on the chemical quality of surface water. PLoS ONE 12(1):12. https://doi.org/10.1371/journ al.pone.0168926

31. Horvatic J, Persic V (2007) The effect of $\mathrm{Ni} 2+, \mathrm{Co} 2+, \mathrm{Zn} 2+, \mathrm{Cd} 2+$ and $\mathrm{Hg} 2+$ on the growth rate of marine diatom Phaeodactylum tricornutum bohlin: microplate growth inhibition test. Bull Environ Contam Toxicol 79(5):494-498. https://doi.org/10.1007/s00128-007-9291-7

32. Heijerick DG, De Schamphelaere KAC, Janssen CR (2002) Biotic ligand model development predicting Zn toxicity to the alga Pseudokirchneriella subcapitata: possibilities and limitations. Comparative Biochemistry and Physiology C-Toxicology \& Pharmacology 133(1-2):207-218. https:// doi.org/10.1016/s1532-0456(02)00077-7 
33. Gillmore ML, Golding LA, Angel BM, Adams MS, Jolley DF (2016) Toxicity of dissolved and precipitated aluminium to marine diatoms. Aquat Toxicol 174:82-91. https://doi.org/10.1016/j.aquatox.2016.02.004

34. Liu JX, Zhou LB, Ke ZX, Li G, Shi RJ, Tan YH (2018) Beneficial effects of aluminum enrichment on nitrogen-fixing cyanobacteria in the South China Sea. Mar Pollut Bull 129(1):142-150. https://doi.org/10.1016/j.marpo |bul.2018.02.011

35. Shi RJ, Li G, Zhou LB, Liu JX, Tan YH (2015) The increasing aluminum content affects the growth, cellular chlorophyll a and oxidation stress of cyanobacteria Synechococcus sp WH7803. Oceanol Hydrobiol Stud 44(3):343-351. https://doi.org/10.1515/ohs-2015-0033

36. DeForest DK, Brix KV, Tear LM, Cardwell AS, Stubblefield WA, Nordheim E, Adams WJ (2020) Updated multiple linear regression models for predicting chronic aluminum toxicity to freshwater aquatic organisms and developing water quality guidelines. Environ Toxicol Chem 39(9):17241736. https://doi.org/10.1002/etc.4796

37. Santore RC, Ryan AC, Kroglund F, Rodriguez PH, Stubblefield WA, Cardwell AS, Adams WJ, Nordheim E (2018) Development and application of a biotic ligand model for predicting the chronic toxicity of dissolved and precipitated aluminum to aquatic organisms. Environ Toxicol Chem 37(1):70-79. https://doi.org/10.1002/etc.4020

38. Bat L, Raffaelli D, Marr IL (1998) The accumulation of copper, zinc and cadmium by the amphipod Corophium volutator (Pallas). J Exp Mar Biol Ecol 223(2):167-184. https://doi.org/10.1016/s0022-0981(97)00162-7

39. Conradi M, Depledge MH (1999) Effects of zinc on the life-cycle, growth and reproduction of the marine amphipod Corophium volutator. Mar Ecol Prog Ser 176:131-138. https://doi.org/10.3354/meps176131

40. Ahearn GA, Mandal PK, Mandal A (2004) Mechanisms of heavy-metal sequestration and detoxification in crustaceans: a review. J Comp Physiol B-Biochem Syst Environ Physiol 174(6):439-452. https://doi.org/10.1007/ s00360-004-0438-0

41. Rainbow PS, Luoma SN (2011) Metal toxicity, uptake and bioaccumulation in aquatic invertebrates-Modelling zinc in crustaceans. Aquat Toxicol 105(3-4):455-465. https://doi.org/10.1016/j.aquatox.2011.08.001

42. Fabrega J, Tantra R, Amer A, Stolpe B, Tomkins J, Fry T, Lead JR, Tyler CR, Galloway TS (2012) Sequestration of zinc from zinc oxide nanoparticles and life cycle effects in the sediment dweller amphipod corophium volutator. Environ Sci Technol 46(2):1128-1135. https://doi.org/10.1021/ es202570g

43. McAfee BJ, Gould WD, Nadeau JC, da Costa ACA (2001) Biosorption of metal ions using chitosan, chitin, and biomass of Rhizopus oryzae. Sep Sci Technol 36(14):3207-3222. https://doi.org/10.1081/ss-100107768
44. Tarpani RRZ, Lapolli FR, Lobo-Recio MA (2015) Removal of aluminum from synthetic solutions and well water by chitin: batch and continuous experiments. Desalin Water Treat 53(13):3531-3542. https://doi. org/10.1080/19443994.2013.873741

45. Anastopoulos I, Bhatnagar A, Bikiaris DN, Kyzas GZ (2017) Chitin Adsorbents for Toxic Metals: a Review. Int J Mol Sci 18(1):11. https://doi. org/10.3390/ijms18010114

46. Lobo-Recio MA, Lapolli FR, Belli TJ, Folzke CT, Tarpani RRZ (2013) Study of the removal of residual aluminum through the biopolymers carboxymethylcellulose, chitin, and chitosan. Desalin Water Treat 51(7-9):17351743. https://doi.org/10.1080/19443994.2012.715133

47. Becker JS, Zoriy M, Matusch A, Wu B, Salber D, Palm C, Becker JS (2010) Bioimaging of metals by laser ablation inductively coupled plasma mass spectrometry (LA-ICP-MS). Mass Spectrom Rev 29(1):156-175. https://doi. org/10.1002/mas.20239

48. Pozebon D, Scheffler GL, Dressler VL (2017) Recent applications of laser ablation inductively coupled plasma mass spectrometry (LA-ICP-MS) for biological sample analysis: a follow-up review. J Anal At Spectrom 32(5):890-919. https://doi.org/10.1039/c7ja00026j

49. Pozebon D, Scheffler GL, Dressler VL, Nunes MAG (2014) Review of the applications of laser ablation inductively coupled plasma mass spectrometry (LA-ICP-MS) to the analysis of biological samples. J Anal At Spectrom 29(12):2204-2228. https://doi.org/10.1039/c4ja00250d

50. Walton RC, McCrohan CR, Livens F, White KN (2010) Trophic transfer of aluminium through an aquatic grazer-omnivore food chain. Aquat Toxicol 99(1):93-99. https://doi.org/10.1016/j.aquatox.2010.04.003

51. Buck BH, Krause G, Michler-Cieluch T, Brenner M, Buchholz CM, Busch JA, Fisch R, Geisen M, Zielinski O (2008) Meeting the quest for spatial efficiency: progress and prospects of extensive aquaculture within offshore wind farms. Helgoland Mar Res 62(3):269-281. https://doi.org/10.1007/ s10152-008-0115-x

52. Di Tullio GR, Mariani P, Benassai G, Di Luccio D, Grieco L (2018) Sustainable use of marine resources through offshore wind and mussel farm co-location. Ecol Model 367:34-41. https://doi.org/10.1016/j.ecolm odel.2017.10.012

\section{Publisher's Note}

Springer Nature remains neutral with regard to jurisdictional claims in published maps and institutional affiliations.

\section{Submit your manuscript to a SpringerOpen ${ }^{\circ}$ journal and benefit from:}

- Convenient online submission

- Rigorous peer review

- Open access: articles freely available online

- High visibility within the field

- Retaining the copyright to your article

Submit your next manuscript at springeropen.com 